\title{
PENGARUH PENGGUNAAN LEMBAR KERJA SISWA (LKS) BERBASIS INKUIRI TERBIMBING PADA MATERI HIDROLISIS GARAM TERHADAP HASIL BELAJAR SISWA KELAS XI SMAN 13 PADANG
}

\author{
Elma Fadrita Rahman, Mawardi, Rahadian Zainul \\ Jurusan Kimia, Universitas Negeri Padang, Indonesia \\ 'elmafadritar@gmail.com
}

\begin{abstract}
This study aims to reveal the effect of the use of Student Worksheets based guided inquiry on salt hydrolysis material to the results of student learning class XI SMAN 13 Padang. This research is quasi experiment research, with research design Randomized Control Group Posttest Only Design. The population of this study is all students of class XI MIA SMAN 13 Padang 2016/2017. The sample was taken randomly by Purposive Sampling technique. The research instrument used is the result of learning test in the form of multiple choice questions. From the research result it can be disclosed that in the cognitive domain of experimental class using guided inquiry-based student worksheets obtain the average of learning result 80,5 and control class using student worksheets used by school (not based on guided inquiry) get the average result of learning result 73, 29. After the t-test at the real level of 0,05

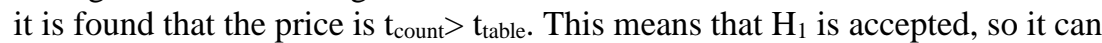
be concluded that students learning outcomes using student worksheets based on inquiry are guided on salt hydrolysis material significantly higher than student worksheets used by school (not based on guided inquiry).
\end{abstract}

Keywords: Salt Hydrolysis, Student Worksheet (LKS), Guided Inquiry, Learning outcomes.

\section{PENDAHULUAN}

Ilmu kimia merupakan ilmu yang mempelajari tentang materi dan perubahan yang menyertainya $^{[1]}$. Ilmu kimia mempelajari sifat materi, struktur materi, perubahan materi, hukum-hukum dan prinsip-prinsip yang menggambarkan perubahan materi, serta konsep-konsep dan teori-teori yang menafsirkan (menjelaskan) perubahan materi. Pembelajaran kimia tidak hanya bertujuan untuk menyampaikan teori-teori, tetapi juga mengembangkan kemampuan sains siswa. Agar pelaksanaan pembelajaran berjalan secara efektif dan efisien maka diperlukan sebuah perencanaan yang tersusun secara sistematis $^{[2]}$.

Hidrolisis garam merupakan salah satu materi ajar kimia yang dipelajari kelas XI SMA pada semester dua. Dalam hidrolisis garam indikator yang harus dicapai oleh peserta didik yaitu (1) menentukan sifat larutan garam melalui percobaan, (2) menjelaskan pengertian hidrolisis garam, (3) mengelompokkan garam yang dapat hidrolisis dan yang tidak dapat terhidrolisis, (4) membedakan garam yang mengalami hidrolisis parsial dan hidrolisis total, (5) menghitung $\mathrm{pH}$ dari jenis garam yang dapat terhidrolisis dalam air.

Pembelajaran kimia tidak akan efektif tanpa adanya pengalaman laboratorium dikarenakan ilmu kimia merupakan ilmu yang lahir melalui proses laboratorium ${ }^{[15-21]}$. Oleh sebab itu, harus disajikan dalam bentuk aktivitas di dalam kelas dan laboratorium. Pembelajaran kimia yang memuat kedua komponen tersebut akan membantu siswa untuk memahami ilmu kimia seutuhnya ${ }^{[3]}$. Salah satu model pembelajaran yang dapat digunakan untuk mempelajari materi hidrolisis garam adalah model pembelajaran inkuiri. Model pembelajaran inkuiri yang dapat diterapkan dalam proses pembelajaran kimia adalah inkuiri terbimbing, yang terdiri dari lima tahapan yaitu orientasi, ekplorasi, pembentukan konsep, aplikasi, dan penutup ${ }^{[4]}$.

Media pembelajaran yang dapat digunakan dalam menerapkan model pembelajaran inkuiri terbimbing salah satunya LKS yang berbasis inkuiri terbimbing. Sebagai pendukung model pembelajaran inkuiri terbimbing digunakan multipel representasi, yang teridiri dari tiga tingkatan yang 
saling memiliki interkoneksi yaitu level makroskopik, level submikroskopik dan level simbolik ${ }^{[5]}$. Model pembelajaran inkuiri terbimbing dapat meningkatkan antusias siswa dalam pelaksanaan kegiatan pembelajaran dan siswa menjadi fokus dalam pelaksanaan pembelajaran ${ }^{[15-21]}$.

Berdasarkan hasil tanya jawab dengan guru dan beberapa siswa SMAN 13 Padang diperoleh informasi bahwa belum bahan ajar yang digunakan sekolah adalah buku paket kimia penerbit Erlangga dan LKS bukan berbasis inkuiri terbimbing. Bahan ajar hanya membahas materi berdasarkan level makroskopik dan level simbolik sedangkan level submikroskopik belum terlihat. Hal ini menyebabkan siswa sulit memahami pelajaran kimia karena interkoneksi antara level representasi (makroskopik, submikroskopik, dan simbolik) belum maksimal. Kegiatan praktikum yang terdapat pada LKS bukan berbasis inkuiri terbimbing berisi tahapan-tahapan yang harus dilakukan didalam laboratorium, siswa tidak dituntut untuk mengetahui apa alasan tahapan tersebut dilakukan serta belum mampu membantu siswa untuk menemukan konsep sendiri, berpikir ilmiah secara kritis, kreatif, mandiri serta rendahnya tingkat pemahaman peserta didik terhadap konsep yang dipelajari. Permasalahan lain yang dihadapi adalah kurangnya keterlibatan siswa secara aktif dalam proses pembelajaran. Kondisi pembelajaran yang diharapkan dapat mendorong peserta didik dalam mencari tahu dari berbagai sumber melalui observasi, dan bukan hanya diberi tahu ${ }^{[6]}$.

Lembar Kerja Siswa (LKS) berbasis inkuiri terbimbing yang memuat aktivitas di kelas dan laboratorium pada materi hidrolisis garam disusun oleh Retno Farah Delima pada tahun 2016 telah memenuhi validitas dan praktikalitas namun belum diuji efektifitas terhadap hasil belajar. Penelitian ini bertujuan untuk mengungkapkan pengaruh penggunaan Lembar Kerja Siswa (LKS) berbasis inkuiri terbimbing pada materi hidrolisis garam terhadap hasil belajar siswa kelas XI SMAN 13 Padang.

\section{METODE PENELITIAN}

Jenis penelitian ini merupakan penelitian eksperimen semu (quasi experiment research). Penelitian eksperimen semu merupakan penelitian yang tidak mengontrol semua variabel yang berhubungan dengan sampel kecuali beberapa veriabel yang diperlukan di dalam penelitian ${ }^{[7]}$.

Desain penelitian yang diterapkan ini adalah Randomized Control Group Posttest Only Design. Populasi adalah objek atau subjek yang telah tergeneralisasi yang mempunyai kualitas dan karakteristik tertentu yang ditetapkan oleh peneliti untuk dipelajari dan kemudian ditarik kesimpulannya ${ }^{[8]}$. Populasi dalam penelitian ini adalah seluruh siswa kelas XI MIA (5 kelas) SMAN 13 Padang pada tahun ajaran 2016/2017.. Pengambilan sampel dilakukan dengan teknik random purposive sampling. Teknik purposive sampling merupakan teknik penentuan sampel dengan pertimbangan tertentu ${ }^{[8]}$ didapatkan kelas sampel pada penelitian ini adalah kelas XI MIA 5 sebagai kelas eksperimen dan kelas XI MIA 4 sebagai kelas kontrol. Kelas eksperimen menggunakan LKS berbasis inkuiri terbimbing dan kelas kontrol menggunakan LKS yang disediakan sekolah.

Penelitian dilakukan 3 tahap yaitu, tahap persiapan, tahap pelaksanaan dan tahap penyelesaian. Pada tahap persiapan dilakukan pembuatan RPP, uji coba soal dan analisis soal. Soal yang diuji cobakan sebanyak 40 soal, dengan jenis soal objektif. Setelah dilakukan uji coba dan analisis soal didapatkan 25 soal yang layak digunakan sebagai tes akhir. Pada tahap pelaksanaan dilakukan kegiatan pembelajaran. Pengujian tes akhir dan pengolahan data tes akhir dan data pengamatan dilakukakan pada tahap penyelesaian.

\section{HASIL DAN PEMBAHASAN}

3.1. Hasil Penelitian

1. Deskripsi Data

Data yang diperoleh berupa hasil belajar siswa pada ranah kognitif dari 32 siswa dari kelas eksperimen dan 31 siswa dari kelas kontrol. Rata-rata yang didapatkan kelas eksperimen dan kelas kontrol berturut-turut adalah 80,5 dan 73,29.

2. Analisis Data

Analisis data dilakukan dengan cara berurutan, mulai dari melihat perbedaan nilai kelas eksperimen dan kelas kontrol, uji normalitas, uji homogenitas dan uji-t. Nilai hasil belajar siswa pada kelas eksperimen dan kelas kontrol dilakukan perhitungan, sehingga diperoleh nilai rata-rata $(\bar{x})$, simpangan baku (S), dan varians (S2). Dari kedua kelas sampel, diperoleh data pada Tabel 1. 
Tabel 1.Nilai Rata-Rata, Nilai Tertinggi, Nilai Terendah, Simpangan Baku, dan Varians Kelas Sampel.

\begin{tabular}{ccccccc}
\hline Kelas & $\mathrm{N}$ & $\begin{array}{c}\text { Nilai } \\
\text { Tertinggi }\end{array}$ & $\begin{array}{c}\text { Nilai } \\
\text { Terendah }\end{array}$ & $\bar{X}$ & $S$ & $S^{2}$ \\
\hline Eksperimen & 32 & 96 & 64 & 80,5 & 8,784 & 77,16 \\
Kontrol & 31 & 92 & 56 & 73,29 & 10,244 & 104,94 \\
\hline
\end{tabular}

Dari Tabel 1 terlihat bahwa hasil belajar siswa kelas eksperimen lebih tinggi dari pada kelas kontrol. Untuk mengetahui apakah terdapat pengaruh signifikan penggunaan LKS berbasis inkuiri terbimbing maka dilakukan uji hipotesis. Uji hipotesis didasarkan pada uji normalitas dan homogenitas pada kedua kelas sampel. Analisis uji normalitas dirangkum pada Tabel 2.

Tabel 2. Hasil Uji Normalitas Tes Akhir Kelas Sampel

\begin{tabular}{cccccc}
\hline Kelas & $\alpha$ & $\mathrm{N}$ & $L_{o}$ & $L_{t}$ & Distribusi \\
\hline Eksperimen & & 32 & 0,110 & 0,157 & Normal \\
Kontrol & 0,05 & 31 & 0,118 & 0,159 & Normal \\
\hline
\end{tabular}

Dari Tabel 2 diketahui harga $\mathrm{L}_{0}<\mathrm{L}_{\mathrm{t}}$ pada taraf nyata 0,05 . Hal ini menunjukkan bahwa data hasil tes akhir kedua kelas sampel terdistribusi normal.

Untuk menentukan kedua kelas sampel memiliki varian yang homogen atau tidak dilakukan uji homogenitas. Analisis uji homogenitas hasilnya dirangkum pada Tabel 3.

Tabel 3. Hasil Uji Homogenitas Tes Akhir Kelas Sampel

\begin{tabular}{lcrrrr}
\hline \multicolumn{1}{c}{ Kelas } & $\alpha$ & $\mathrm{N}$ & $F_{h}$ & $F_{t}$ & Keterangan \\
\hline $\begin{array}{l}\text { Eksperimen } \\
\text { Kontrol }\end{array}$ & 0,05 & $\begin{array}{r}32 \\
31\end{array}$ & 1,36 & 1,84 & Homogen \\
\hline
\end{tabular}

Dari Tabel 3 diketahui harga $F h$ pada masing-masing kelas sampel lebih kecil daripada harga $F \mathrm{t}$ nya. Hal ini menunjukkan bahwahasil kompetensi kognitif kedua kelas sampel memiliki varians yang homogen.

Dari hasil uji normalitas dan uji homogenitas kedua kelas sampel menunjukkan bahwa kedua kelas terdistribusi normal dan mempunyai varians yang homogen. Oleh karena itu untuk menguji hipotesis digunakan uji $\mathrm{t}$ dan data hasil uji hipotesis terangkum pada Tabel 4.

Tabel 4. Hasil Uji Hipotesis terhadap Hasil Tes Akhir Kelas Sampel

\begin{tabular}{ccccccc}
\hline Kelas & $\mathrm{N}$ & $\bar{X}$ & $\mathrm{~S}$ & $\mathrm{~S}^{2}$ & thitung & tabel \\
\hline Eksperimen & 32 & 80,5 & 8,784 & 77,16 & & \\
Kontrol & 31 & 73,29 & 10,244 & 104,94 & 3,15 & 1,67 \\
\hline
\end{tabular}

Berdasarkan analisis yang telah dilakukan didapatkan $t_{\text {hitung }}>t_{\text {tabel }}$, sehingga $\mathrm{H}_{0}$ ditolak pada taraf nyata 0,05 . Hal ini menunjukkan bahwa hasil belajar siswa dengan menggunakan LKS berbasis inkuiri terbimbing lebih tinggi secara signifikan daripada hasil belajar siswa yang menggunakan LKS yang digunakan sekolah (bukan berbasis inkuiri terbimbing).

\subsection{Pembahasan}

Model pembelajaran inkuiri terbimbing merupakan model pembelajaran yang berpusat pada siswa, siswa bekerja dalam kelompok-kelompok kecil dengan peran individu untuk memastikan bahwa semua siswa terlibat penuh dalam proses pembelajaran yang membuat siswa lebih mengerti dan mengingat lebih lama ${ }^{[9]}$. Model pembelajaran inkuiri memberikan kesempatan kepada siswa 
untuk mempelajari cara menemukan fakta, konsep dan prinsip melalui pengalamannya secara langsung ${ }^{[10]}$. Proses pembelajaran pada materi hidrolisis garam di kelas eksperimen dan kelas kontrol sama-sama menggunakan model pembelajaran inkuiri terbimbing. Proses pembelajaran inkuiri terbimbing terdiri dari 5 tahap, yaitu orientasi, eksplorasi, pembentukan konsep, aplikasi dan penutup ${ }^{[11]}$, yang membedakan antara kelas eksperimen dan kelas kontrol adalah LKS yang digunakan. Pada kelas ekperimen LKS yang digunakan adalah LKS berbasis inkuiri terbimbing yang disusun oleh Retno Farah Delima, S.Pd., sedangkan kelas kontrol menggunakan LKS yang digunakan sekolah (bukan berbasis inkuiri terbimbing).

Materi hidrolisis garam dapat dipelajari di dalam kelas dan di laboratorium. Pembelajaran dengan menggunakan LKS berbasis inkuiri terbimbing yang memuat aktivitas di kelas dan di laboratorium membuat siswa lebih aktif dalam proses pembelajaran. Tahap orientasi meliputi mempersiapkan siswa dalam pembelajaran dimana guru memberikan motivasi, menyampaikan tujuan pembelajaran sehingga menghasilkan rasa ingin tau siswa dan membuat koneksi antara preknowledge dengan materi yang akan dipelajari. Proses pembelajaran dengan penggunaan LKS berbasis inkuiri terbimbing dapat membantu siswa mengembangkan pemahaman dengan siklus belajar kelompok. Hal ini sesuai dengan pernyataan bahwa pembelajaran inkuiri terbimbing akan lebih efektif selama pembelajaran berlangsung siswa bekerja dalam sebuah tim ${ }^{[11]}$. Penelitian sebelumnya menjelaskan bahwa inkuiri terbimbing dapat meningkatkan motivasi siswa dalam pembelajaran sains ${ }^{[12]}$. Dengan melibatkan siswa dalam proses pembelajaran dapat memberikan kesempatan siswa untuk mengembangkan dirinya dan terampil berpikir kritis.

Pada tahap eksplorasi, siswa mengamati dan menganalisis model yang terdapat pada LKS berbasis inkuiri terbimbing dan dipandu dengan pertanyaan kunci. Sejalan dengan pendapat Rahmiati menyatakan penggunaan LKS dapat memberikan petunjuk kepada siswa dalam menemukan konsep dengan mengamati model yang difokuskan pada pembelajaran ${ }^{[13]}$. Pertanyaan kunci menuntun siswa untuk berpikir kritis, analitis, sebagai representasi level submikroskopik terhadap visualisasi konsep sehingga dapat mengarahkan untuk mencari informasi, mengkoneksikan, membuat kesimpulan yang tepat dan dapat mengkonstruksi pemahaman konsep yang dipelajari ${ }^{[11]}$. Ketika siswa mengeksplorasi dari model atau informasi dan menjawab pertanyaan kunci, berarti siswa telah memasuki tahap pembentukan konsep.

Model yang terdapat pada LKS dibuat berwarna. Penggunaan warna dan desain pada gambar sangat membantu siswa untuk tertarik dalam belajar ${ }^{[13]}$. Pertanyaan kunci menuntut siswa berpikir kritis menemukan jawaban dari pertanyaan kunci dengan memanfaatkan model yang ada pada LKS sehingga siswa dapat membangun konsep mereka sendiri.

Berbeda halnya dengan LKS kelas kontrol menggunakan LKS yang digunakan sekolah (bukan berbasis inkuiri terbimbing). Kurangnya pemodelan membuat siswa tidak memiliki kesempatan untuk memahami materi yang disajikan serta tidak dilengkapi dengan pertanyaan kunci. Siswa lebih cenderung menghafal konsep, padahal konsep yang ditemukan sendiri oleh siswa akan memberikan pemahaman yang lebih baik untuk bisa diingat lebih lama dibandingkan hafalan yang sifatnya sementara.

Tahap aplikasi merupakan tahapan pemberian latihan dan soal. Pada kelas eksperimen siswa lebih baik dalam mengerjakan soal yang terdapat pada LKS kelas eksperimen daripada kelas kontrol. Hasil analisis jawaban siswa pada LKS berbasis inkuiri terbimbing menunjukkan rata-rata nilai 90. Hampir seluruh dari isi LKS dapat dikerjakan siswa. Kesulitan siswa dalam pengerjaan LKS terdapat pada penurunan rumus menghitung $\mathrm{pH}$. Hal ini terlihat dari seringnya siswa meminta penjelasan atau bantuan dari guru. Pada tahap penutup, kelas eksperimen terlihat lebih baik dalam menyampaikan hasil diskusi. Hal ini sesuai dengan penelitian yang dilakukan oleh Bilgin, siswa yang belajar dengan menggunakan model pembelajaran inkuiri terbimbing lebih mudah mengerti dan memahami konsep pelajaran serta meningkatkan efektivitas interaksi, membangun tim, pembelajaran dan minat melalui kerja kelompok yang sangat terstruktur ${ }^{[14]}$.

\section{KESIMPULAN}

Berdasarkan hasil penelitian dan analisis data yang telah dilaksanakan disimpulkan bahwa penggunaan LKS berbasis inkuiri terbimbing pada materi hidrolisis garam berpengaruh terhadap hasil belajar siswa. Hasil belajar siswa yang belajar dengan menggunakan LKS berbasis inkuiri terbimbing dengan rata-rata 80,5 lebih tinggi secara signifikan daripada kelas kontrol dengan rata-rata 73,29 yang 
menggunakan LKS bukan inkuiri terbimbing pada materi hidrolisis garam di kelas XI SMAN 13 Padang.

\section{REFERENSI}

[1] Chang, R. 2004. Kimia Dasar : Konsep - Konsep Inti Jilid I. Jakarta : Erlangga.

[2] Hamalik, Oemar. 2012. Kurikulum dan Pembelajaran. Jakarta: PT Bumi Aksara.

[3] American Chemical Society Committee on Education. 2012. "ACS Guidelines and Recommendations for the Teaching of High School Chemistry". American Chemical Society, pp. $1-28$.

[4] Hosnan. 2014. Pendekatan Saintifik dan Kontekstual dalam Pembelajaran Abad 21. Bogor: Ghalia Indonesia.

[5] Sunyono. 2012. "Kajian Teoritik Model Pembelajaran Kimia Berbasis Multipel Representasi (Simayang) dalam Model Mental Pebelajar". Prosiding Seminar Nasional Sains, Universitas Negeri Surabaya, 14 Januari 2012 Hal. 486-495.

[6] Daryanto. 2014. Pendekatan Pembelajaran Saintifik Kurikulum 2013. Yogyakarta: Gava Media.

[7] Suryabrata, S. 2013. Metodologi Penelitian. Jakarta : Rajawali Pers.

[8] Sugiyono. 2012. Metode Penelitian Pendidikan. Bandung: Alfabeta.

[9] Straumanis, Andrei. (2010). Process Oriented Guided Inquiry Learning.

[10] Permatasari, R.E. 2014. "Implementasi Model Pembelajaran Inkuiri Terbimbing Pada Materi Sifat Koligatif Larutan”. Jurnal Pena Sains. Vol.1(2).

[11] Hanson, D., M. 2005. "Designing Process-Oriented Guided-Inquiry Activities". In Faculty Guidedbook: A Comprehensive Tool For Improving Faculty Performance, pp.1-6.

[12] Patrick, H. 2009. "Motivation for Learning Science in Kindergarten: Is There a Gender Gap and Does Integrated Inquiry and Literacy Instruction Make a Difference”. Journal Of Research In Science Teaching. Vol. 46 (2): 166-191.

[13] Rahmiati, S. Mawardi. 2016. "Teaching Materials Development of Student Word Sheet (SWS) Guided Inquiry Based on The Materials for Learning Rate of Chemical Reaction”. Proceedings of Academics World $28^{\text {th }}$ International Conference, Tokyo, Japan, $28^{\text {th }}$ March 2016.

[14] Bilgin, I. 2009. The Effects of Guided Inqury Instruction Incorporating, a Cooperative Learning Approach on University Students 'Achievement of Acid and Bases Concepts and Attitude Toward Guided Inqury Instruction. SRE, 4 (10): 1038-1046.

[15] Zainul, R. (2016, February 19). Disain, Metode dan Penggunaan Software Pembelajaran Kimia Berbasis IT untuk Aktivitas Kelas dan Laboratorium Berbasis Inkuiri Terbimbing. https://doi.org/10.31227/osf.io/psf5t

[16] Handayani, D. P., Zainul, R., \& Azra, F. (2018, February 1). Pengembangan Multimedia Prezi Berbasis Problem Based Learning (PBL) pada Materi Hukum-Hukum Dasar Kimia Kelas X IPA di SMAN 1 Bukittinggi. https://doi.org/10.31227/osf.io/yqpem

[17] Lusi, D. F., Y., \& Zainul, R. (2018, May 7). Efektivitas Modul Larutan Elektrolit dan Nonelektrolit Berbasis Discovery Learning Terhadap Keterampilan Berpikir Kritis dan Hasil Belajar Siswa Kelas X MIPA SMAN 2 Bukittinggi. https://doi.org/10.31227/osf.io/b2vtx

[18] Maypalita, F., M., \& Zainul, R. (2017, August 16). Pengaruh Penggunaan Lembar Kerja Siswa (LKS) Berbasis Inkuiri Terbimbing pada Materi Larutan Penyangga terhadap Hasil Belajar Siswa Kelas XI IPA SMAN 5 Padang. https://doi.org/10.31227/osf.io/j3fxc

[19] Putri, G. A., H., \& Zainul, R. (2017, August 24). Development of Periodic Table Interactive Instructional Multimedia in Chemistry Lesson For Xth Grade SMA/MA. https://doi.org/10.31227/osf.io/2hsme

[20] Murni, H. P., Dj, L., \& Zainul, R. (2017, January 2). Pengembangan Penuntun Praktikum Kimia Berorientasi Chemoentrepreneurship untuk SMA/MA Kelas XII Semester Ganjil. https://doi.org/10.31227/osf.io/m23ac

[21] Sepriandi, P., E., \& Zainul, R. (2016, August 15). Pengembangan LKS Dengan Pendekatan Saintifik Berbasis Discovery Learning pada Materi Asam Basa untuk Pembelajaran Kimia Kelas XI SMA/MA. https://doi.org/10.31227/osf.io/5cb3h 
Aumi, V., M., \& Zainul, R. (2016, April 19). Pengembangan Bentuk Lembar Kerja Siswa (LKS) untuk Aktivitas Kelas dan Laboratorium Berbasis Inkuiri Terbimbing pada Pokok Bahasan Laju Reaksi. https://doi.org/10.31227/osf.io/7rszp

H., Azhar, M., \& Zainul, R. (2018, April 9). THE EFFECTIVENESS OF STRUCTURED INQUIRY BASED MODULE TO IMPROVE MENTAL MODEL OF CONCEPT MOLE. https://doi.org/10.31227/osf.io/ckjtb 
